\title{
Las devociones religiosas en la España Moderna
}

Religious devotions in Modern Spain (16th.-18th. centuries)

Ramón Maruri Villanueva Universidad de Cantabria

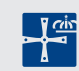




\section{RESUMEN}

En este estudio se tratan las claves explicativas de la profunda renovación conocida por la historiografía modernista española desde la década de 1980 en el análisis de las devociones, uno de los componentes de la religiosidad. Una renovación en la que, independientemente de la multiplicación de las aportaciones, han primado muy considerablemente las enmarcadas en el ámbito local, lo cual se ha traducido en un conocimiento muy sectorial y fragmentado del universo devocional. Articular lo ya conocido y trascender analíticamente la escala local se proponen como los dos grandes retos a los que se enfrenta el investigador de las devociones en la España Moderna.

Palabras clave

Devociones, Religiosidad, Mentalidades, España Moderna.

\section{AbSTRACT}

This study gives an account of the explanatory keys of the profound renovation that has been occurring in Spanish modernist historiography since the 1980s in the analysis of devotions, a component of religiosity. A renovation in which, regardless of the multiplication of contributions, these have prevailed very considerably framed at the local level, which has resulted in a very sectorial and fragmented knowledge of the devotional universe. Articulating what is already known, and transcending the local scale are proposed as the two great challenges faced by the researcher of devotions in modern Spain.

KeY Words

Devotions, Religiosity, Mentalities, Modern Spain.

Recibido: 5 de julio de 2017. Aceptado: 4 de septiembre de 2017.

El presente trabajo forma parte de una investigación más amplia sobre vivir la religión en la Cantabria de la transición del Antiguo Régimen a la sociedad liberal y se enmarca en el proyecto financiado por el Plan Nacional de I+D+I Iglesia, discursos religiosos y control social en la crisis del Antiguo Régimen y la revolución liberal (HAR209-10561), dirigido por el Dr. Rafael Serrano García, de la Universidad de Valladolid. 
Todavía hoy, como manifestación de lo que Braudel denominara «las prisiones de larga duración» que son las mentalidades, bien individuales, bien colectivas, entrar en un templo de una localidad — da igual su magnitud — y observar el panteón de seres sagrados que reposan en altares mayores, capillas, paredes, vitrales o sacristías es situarse ante uno de los testimonios más elocuentes del universo devocional de las gentes en la longue durée; poco importa que continúen, o no, recibiendo culto o moviendo a los fieles a hacerles objetos de su devoción. Lo que importa es, conforme a la multisecular y bien probada experiencia de la Iglesia católica en que todo permanezca igual, que ahí siguen. Como también pueden quedar en el templo testimonios de longevas cofradías y hermandades ${ }^{1}$, de arcas de misericordia, de catafalcos con el féretro destinado a los pobres que ni para pagarse uno tenían, etcétera. Al igual que en los archivos diocesanos reposa documentación manuscrita e impresa que da fe de plurales manifestaciones del mundo devocional en la España Moderna.

En sentido estricto, y así se entendía en el siglo XVIII, devoción era adorar, venerar y dar culto a Dios, a la Virgen y a los Santos ${ }^{2}$. Para un historiador hoy, hacer de las devociones un objeto de conocimiento supone trascender los bien acotados límites eclesiásticos de lo religioso. Supone dar cuenta de un hecho de cultura, en el que confluyen, además de, por supuesto, la creencia, lo económico, lo social, lo político o lo artístico; en otras palabras, a las devociones las abraza el todo social. Haber llegado a entenderlas así exige, por lo que a la historiografía española se refiere, establecer, al menos, dos grandes secuencias.

La primera tiene un doble enmarque: por un lado, el del paradigma de la erudición historicista, que presta atención al acontecimiento particular, describiéndolo y descontextualizándolo, sin más; y, por otro, el de la realidad político-religiosa del nacional-catolicismo, apologista de la catolicidad de España,

1 Sobre cofradías y hermandades, es de ineludible consulta en este monográfico el estudio de Inmaculada Arias de SaAvedra y Miguel L. López-Guadalupe Muñoz.

2 Diccionario de la Lengua Castellana compuesto por la Real Academia Española o Diccionario de Autoridades, Madrid, RAE, 2013 (1. ${ }^{\text {a }}$ ed., 1726-1739) (Edición facsimilar). Una herramienta imprescindible para el estudio de las devociones es Andrea Riccardi, Carla Leonardi y Gabriella ZarRi (dirs.), Diccionario de los santos, Madrid, Ed. San Pablo, 2000, 2 vols. No obstante las numerosas aportaciones cuantitativas y cualitativas de esta obra, continúa siendo de utilidad Santiago de la Vorágine, La leyenda dorada, Madrid, Alianza Editorial, 1982, 2 vols. 
testimoniada en la proliferación de devociones locales, comarcales, provinciales, regionales y nacionales, estas últimas encarnadas por antonomasia en la devoción a la Virgen bajo sus múltiples advocaciones; en torno a la devoción a la del Pilar y a la devoción a Santiago se articulaba la identidad nacional. No obstante, he de precisar que a lo particular y a lo descriptivo no les doy en todos los casos sentido peyorativo alguno, pues interesarse por lo que da especificidad a una devoción en una determinada localidad es para el historiador un punto de partida de necesidad; cosa bien diferente es que la especificidad se confunda con lo anecdótico y que se le dirija una mirada sociocéntrica, autocomplaciente con la exaltación de lo propio en detrimento de lo ajeno. En otras palabras, el cuestionamiento de lo particular y lo descriptivo nada tiene que ver con lo genuinamente etnográfico, reivindicado por quienes en la actualidad marcan los rumbos de la Antropología Social en España ${ }^{3}$.

La segunda secuencia historiográfica corresponde a un radicalmente nuevo contexto, como es el de la Constitución de 1978, fundamento del Estado aconfesional, acompañado este por un proceso social de secularización y de indiferentismo religioso. Un contexto que, sin embargo, no ha generado colateralmente una retracción de los estudios interesados por el mundo de las devociones; bien al contrario, tales estudios se han incrementado por dos razones. Una de ellas, porque esa misma Constitución instaura el Estado de las Autonomías, lo cual propicia el conocimiento y difusión de las peculiaridades o rasgos diferenciales de cada una de ellas a partir de las diversas escalas espaciales. En buena medida, una parte notable de lo mucho publicado sobre devociones se debe precisamente a la actividad de instituciones, públicas y privadas, religiosas y seculares, que, en los ámbitos local, provincial y regional, promueven la edición de monografías y revistas de contenido histórico, en el que tienen espléndido acomodo los estudios de devociones religiosas propias de tales ámbitos. La otra razón del incremento bibliográfico en materia devocional en España tiene que ver con la profunda transformación que conoce la Universidad, expresión, en palabras de Ángel Gari, del «cambio social y cultural experimentado con la transición política, [que] impulsa la aparición de nuevas asociaciones y grupos que se interesan por recuperar costumbres y tradiciones con enfoques diferentes a los desarrollados en las décadas ante-

\footnotetext{
3 «Sin etnografía no hay antropología» es uno de los apartados de la obra colectiva coordinada por Antonio M. Nogués y Francisco CHEcA, La Cultura Sentida. Homenaje al profesor Salvador Rodríguez Becerra, Sevilla, Signatura Ediciones de Andalucía, 2011; véase en ese apartado Javier Escalera ReYes, «Reivindicación de la Etnografía: a propósito de una primera experiencia etnográfica en la Sierra de Cádiz», págs. 139144. Es también significativa la edición de Zainak. Cuadernos de Antropología-Etnografía.
} 
riores por la cultura oficial» ${ }^{4}$. Una cultura oficial, como he comentado líneas atrás, interesada por lo devocional tan solo como constatación empírica de un «eterno» catolicismo español.

En términos científicos, la transformación de la Universidad se tradujo, por lo que a la disciplina histórica se refiere, en el arrinconamiento del hasta entonces imperante historicismo, derrotado por de los paradigmas historiográficos aportados por la Nueva Historia y por el Materialismo histórico, al que pone voz el marxismo.

La Nueva Historia, sinónimo de la francesa Escuela de Annales, halla su asiento en la década de 1970 en la Universidad de Santiago de Compostela, merced a la labor de Antonio Eiras Roel. Este toma el testigo de Jaume Vicens Vives, introductor en España de los planteamientos annalianos, y crea en torno a él un grupo de investigadores que, partiendo de un inicial interés por lo económico y lo demográfico, muy pronto amplían su territorio investigador incorporando el estudio del «tercer nivel» o mentalidades. Sin embargo, y aun tomando en consideración que las devociones religiosas son indicadores de mentalidades, su estudio no se vio influido inicialmente por la renovación historiográfica impulsada desde la Universidad compostelana. En las cuatro monografías que forman el, digamos, corpus inicial investigador de dicha Universidad se halla del todo ausente lo devocional, como no sean menciones tangenciales en estudios referidos a la religiosidad y a la cultura ${ }^{5}$. En cuanto al Materialismo histórico, el estudio de las devociones, en tanto que componentes de la mentalidad o «blando» sistema ideacional, carecía de interés, a excepción, en su momento en Francia, de Michel Vovelle.

El giro que se produce en la historiografía española relativa a las devociones religiosas vendrá por otra vía, siendo la década de 1980 la que marque un antes y un después. En el replanteamiento del estudio de lo devocional, uno

4 Ángel Gari Lacruz, «Los trabajos de religiosidad popular sobre Aragón desde principios del siglo xx. Estado de la cuestión», Boletín de Literatura Oral, 1 (2017), pág. 275 (el artículo completo, en págs. 273-298). El acrecentamiento de las investigaciones sobre religiosidad popular desde la década de 1980 es observable igualmente en el artículo de José Ignacio Номовоno Martínez, «Bibliografía sobre antropología de la religión», Zainak. Cuadernos de Antropología-Etnografía, 28 (2006), págs. 543-579.

5 VV. AA., Actas de las I Jornadas de Metodología Aplicada de las Ciencias Históricas, Santiago de Compostela, Universidad de Santiago de Compostela / Confederación Española de Cajas de Ahorros, 1975; Antonio Eiras Roel et alii, Las fuentes y los métodos. 15 trabajos de historia cuantitativa serial de Galicia, Santiago de Compostela, Universidad de Santiago de Compostela, 1977; Antonio Eiras Roel y Colaboradores, La historia social de Galicia en sus fuentes de protocolos, Santiago de Compostela, Universidad de Santiago de Compostela, 1981; VV. AA., Actas del II Coloquio de Metodología Histórica Aplicada. La Documentación Notarial y la Historia, Santiago de Compostela, Universidad de Santiago de Compostela-Junta de Decanos de los Colegios Notariales de España, 1984. 
de los afluentes del río de la religiosidad — por excelencia la popular — las aportaciones de la Antropología ocuparán incuestionablemente un lugar central, aun cuando la Historia - al igual que la Etnografía — contaba ya con una larga tradición en cuanto a interesarse por ese mundo ${ }^{7}$. Tal replanteamiento surge inequívocamente, al menos en cuanto a diversificación temática, intensidad analítica y producción bibliográfica, en Andalucía, con el precedente de lo aportado sobre otros ámbitos territoriales por el antropólogo norteamericano William A. Christian en la década de $1970^{8}$. Que fuera Andalucía la impulsora del giro investigador en el campo de las devociones - menciono tan solo estas por ser mi objeto de estudio, pero el giro afectaba, según he comentado, a toda investigación relacionada con la religiosidad popular- se explica cualitativamente en buena medida, según José I. Homobono, por haberse constituido en el Departamento de Antropología Social de la Universidad de Sevilla, en torno a Isidoro Moreno y a Salvador Rodríguez Becerra ${ }^{9}$, dos sólidos grupos de investigación cuyas aportaciones comienzan a ver la luz en la década de 1980, en el marco, como ya indiqué, de la España democrática.

Es en ese tiempo en el que hay que situar el inicio del diálogo, que se irá haciendo permanente y bien fructífero, entre historiadores y antropólogos como expresión de interdisciplinariedad, una de las exigencias esta, por lo que a la Historia se refiere, formuladas por el grupo annaliano desde sus inicios -léase Lucien Febvre y Marc Bloch—, allá por 1929, y que todavía hacia 1970 Fernand Braudel demandaba. Bien pudiera decirse que, aproximadamente hasta esa década, las relaciones de la Historia con la Antropología eran idénticas a

6 Sobre el concepto «religiosidad popular», es de ineludible consulta en este monográfico el estudio de Roberto J. López.

7 Aunque han transcurrido ya casi dos décadas desde su publicación, puede consultarse el artículo de Jesús M. ${ }^{a}$ UsunÁRIZ GARAYOA, «Los estudios sobre religiosidad popular en la España Moderna en los últimos veinticinco años», Zainak. Cuadernos de Antropología-Etnografía, 18 (1999), págs. 17-43 (en págs. 22 y sigs. aporta reflexiones, además de una selecta bibliografía, sobre componentes sustanciales de lo devocional, tales como lugares de culto, reliquias, procesiones, rogativas, apariciones, milagros, fiestas, romerías y agrupaciones. Acúdase también, aunque se refiera a la fiesta, a las reflexiones de Salvador Rodríguez BecErra, "Las fiestas en Andalucía. Perspectivas históricas y antropológicas», cuestión abordada igualmente en su Religión y fiesta. Antropología de las creencias y rituales en Andalucía, Sevilla, Signatura Demos, 2000.

8 William A. Christian (Jr.), «De los santos a María: panorama de las devociones a santuarios españoles desde el principio de la Edad Media hasta nuestros días», en Carmelo Lisón Tolosana (ed.), Temas de Antropología Española, Madrid, Akal, 1976, págs. 49-106; Religiosidad popular. Estudio antropológico en un valle español, Madrid, Tecnos, 1978 (1. a ed. inglesa, 1972). Vendrían después Apariciones en Castilla y Cataluña (Siglos XIV-XVI), Madrid, Nerea, 1990 (1. ' ed. inglesa, 1981); Religiosidad local en la España de Felipe II, Madrid, Nerea, 1991 (1. a ed. inglesa, 1989).

9 Véase José I. Номовоno, reseña de la monografía de Salvador Rodríguez Becerra, Religión y fiesta. Antropología de las creencias y rituales en Andalucía, en Zainak. Cuadernos de Antropología-Etnografía, 26 (2004), págs. 827-828. 
las de la Historia con la Sociología: tormentosas; relaciones que devendrían al final en una estrecha colaboración, puesto que, en última instancia, como afirma el antropólogo Rodríguez Becerra, «Del acercamiento de estas dos disciplinas, la antropología y la historia, solo pueden desprenderse beneficios para el conocimiento de las culturas humanas, lo que en último término nos conduce al conocimiento del hombre» ${ }^{10}$. Si el historiador inició el camino hacia la Antropología, el antropólogo hizo lo mismo respecto a la Historia; sin huir de la contemporaneidad, ámbito cronológico preferente de los antropólogos, estos tomarán muy en consideración el pasado de las sociedades humanas para una cabal comprensión del tiempo presente.

Por los caminos de la Historia y por los de la Antropología comenzó a fluir una bibliografía relativa al mundo de las devociones religiosas que venía a plantear hipótesis, a resolver problemas y a sentar las bases, ya irrenunciables, desde las que abordar las investigaciones de un objeto de conocimiento multifacial, como es la devoción a un ser tenido por sagrado. La irrenunciabilidad a esas bases se entiende cuando de lo que se trata es de estudiar las devociones con criterios de cientificidad y con la más estricta solvencia.

Por los caminos de la Historia y de la Antropología afluyó una ingente cantidad de estudios en diversos soportes, desde la monografía hasta el artículo de revista electrónica, de tal modo que pretender dar cuenta de cada uno de ellos es tarea vana, más aún cuando he de someterme a la disciplina del espacio que, como los demás autores, tengo asignado. Tras considerar diversas opciones una vez recopilados, clasificados y consultados los múltiples materiales de muy diversa procedencia, cronología y temática, me pareció la más abordable y eficaz proporcionar al lector de este estudio, o al investigador que desee orientar sus pasos hacia lo devocional, una nómina de monografías colectivas que cumplieran estos dos requisitos: uno, haberse publicado a partir de 1980, década en la que, según vimos, se producía una redefinición del estudio de las devociones religiosas; y el otro, que, a través de una amplia casuística, pudieran dar cuenta de las diversas perspectivas desde las que puede abordarse actualmente dicho

10 Salvador Rodríguez BecerRa, «Introducción», en Carlos Álvarez Santaló, M. a Jesús Buxó i Rey y Salvador Rodríguez Becerra (coords.), La religiosidad popular, Barcelona / Sevilla, Anthropos / Fundación Machado, 1989, vol. I, pág. 10; este primer volumen lleva por subtítulo Antropología e Historia. Cuatro años después, Isidoro Moreno, en un artículo reivindicador de una Antropología científica y alejada de los modelos anglosajones -léase a través del británico Julian Pitt-Rivers y el estadounidense David Gilmore-, imperantes en España y que habían «colonizado» el «terreno» y las «teorías» en cuanto a interpretación de la realidad social andaluza, apelaba, sin ser la primera vez, a la necesidad de integrar los conocimientos de las Ciencias Sociales y Humanas para la comprensión de esa realidad, Isidoro Moreno NAvArro, «La doble colonització de l'Antropologia andalusa i perspectives de futur», Quaderns de l'Institut Català d'Antropologia, 5 (1984), págs. 69-84. Pueden consultarse también los estudios citados en la nota n. ${ }^{\circ}$. 
estudio — se trata de perspectivas atemporales, por lo tanto aplicables a devociones no circunscritas exclusivamente a la España Moderna; otra cosa son los contextos cronológicos en los que enmarcar tales perspectivas-.

El número de monografías que propongo es de 45, abarcando un arco temporal que va de 1989 a 2017 y cuyo contenido supera el millar de aportaciones, magnitud que estimo altamente representativa del estado actual del conocimiento sobre las devociones en los siglos modernos ${ }^{11}$. Recurriendo a un

11 Para nada haberme centrado en esta base bibliográfica, que detallaré seguidamente, supone minusvalorar lo que se ha aportado en otro tipo de publicaciones, a algunas de las cuales habré de referirme en su momento. Del mismo modo, dada la inviabilidad de citar todos los estudios contenidos en cada una de las monografías recogidas en dicha base, he optado por mencionar algunos casos ilustrativos de las cuestiones que he considerado constituyen lo fundamental en el análisis de las devociones. La ordenación de las monografías es cronológica, y, cuando coincida el año de publicación de más de una, me sirvo del criterio alfabético.

Álvarez Santaló, Buxó i Rey y Rodríguez Becerra (coords.), La religiosidad popular; VV. AA., La Fiesta, la ceremonia, el rito. Coloquio Internacional, Granada, Palacio de la Madraza, 24/26-IX-1987, Granada, Universidad de Granada, 1990; VV. AA., La Orden Concepcionista. Actas del I Congreso Internacional. León, 8 al 12 de mayo de 1989. Monasterio de la Purísima Concepción, León, Universidad de León, 1990, 2 vols.; Emilio La Parra, y Jesús Pradells Nadal (eds.), I Coloquio Internacional Iglesia, Sociedad y Estado en España, Francia e Italia. Siglos XVIII-XX. Niza, 1991, Alicante, Instituto «Juan Gil Albert», 1992; Juan ArANDA Doncel (coord.), Congreso de religiosidad popular en Andalucía, Córdoba, Obra Social y Cultural CajaSur, 1994; Eliseo Serrano Martín (coord.), Muerte, religiosidad y cultura popular: siglos XIII-XVIII, Zaragoza, Institución «Fernando el Católico», 1994; Aranda Doncel (coord.), Actas del Congreso Nacional sobre la advocación de Nuestra Señora de los Remedios. Historia y Arte, Córdoba, CajaSur, 1995; José A. GonzÁLez AlCantud y Salvador Rodríguez Becerra (eds.), Creer y curar: la medicina popular, Granada, Diputación Provincial, 1996; Francisco J. Campos y Fernández de Sevilla (dir.), Religiosidad popular en España. Actas del Simposium San

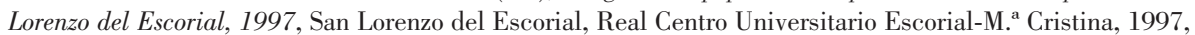
2 vols.; José Ruiz Fernández y Valeriano Sánchez Ramos (coords.), La religiosidad popular y Almería. Actas de las I Jornadas de religiosidad popular. 1996, Almería, Instituto de Estudios Almerienses, 1998; Salvador Rodríguez Becerra (coord.), Religión y Cultura. Actas del II Congreso de Religiosidad Popular. Andújar, 1997, Sevilla, Junta de Andalucía / Fundación Machado, 1999, 2 vols.; David GonzÁLEz Cruz (ed.), Religiosidad y costumbres populares en Iberoamérica. Actas del Primer Encuentro Internacional. Celebrado en Almonte-El Rocío (España) del 19 al 21 de febrero de 1999, Huelva, Universidad de Huelva, 2000; Ramón Maruri Villa-

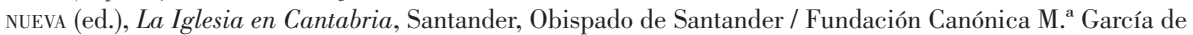
Noreña, 2000; José Ruiz Fernández y Valeriano Sánchez Ramos (coords.), La religiosidad popular y Almería. Actas de las II Jornadas de religiosidad popular. 1998, Almería, Instituto de Estudios Almerienses, 2001; David González Cruz (ed.), Ritos y Ceremonias en el Mundo Hispano durante la Edad Moderna. Actas del Segundo Encuentro Iberoamericano de Religiosidad y Costumbres Populares. Celebrado en Almonte-El Rocío (España) del 23 al 15 de Noviembre de 2001, Huelva, Universidad de Huelva, 2002; Juan Aranda Doncel (coord.), Las advocaciones marianas de Gloria (Actas del I Congreso Nacional de advocaciones de la luz. 2002), Córdoba, CajaSur, 2003, 2 vols.; Francisco J. Campos y Fernández de Sevilla (dir.), Religiosidad y ceremonias en torno a la Eucaristía. Actas del Simposium San Lorenzo del Escorial, 2003, San Lorenzo del Escorial, Real Centro Universitario Escorial-M. ${ }^{a}$ Cristina, 2003, 2 vols.; Valeriano SÁnchez Ramos y José Ruiz Fernández (coords.), La religiosidad popular y Almería. Actas de las III Jornadas de religiosidad popular. 2004, Almería, Instituto de Estudios Almerienses, 2004; VV. AA., Santiago y la Monarquía de España (1504-1788), Madrid, Sociedad Estatal de Conmemoraciones Culturales, 2004; Julio Ramos Guerreira, Miguel A. Pena González y Francisco Rodríguez Pascual (eds.), La religiosidad popular. Riqueza, discernimiento y retos, Salamanca, Universidad Pontificia de Salamanca, 2004; Juan Aranda Doncel (coord.), La Advocación de la Salud. Actas del I Congreso Nacional, Aguilar de la Frontera, Ayuntamiento de Aguilar de la Frontera, 2005; Francisco J. 
elemental ejercicio de cuantificación de la muestra, se evidencia la centralidad de Andalucía en la renovación de dicho conocimiento: de las 45 monografías, $30(66,7 \%)$ son promovidas desde esa Comunidad Autónoma —Córdoba (12), Almería (9), Granada (2), Huelva (2), Málaga (2) y Sevilla-Barcelona (3)—. Además del papel que les cupo a universidades andaluzas en la renovación, es de destacar el impulso dado por otras instituciones, públicas y privadas, a la investigación sobre religiosidad y a su difusión, como es el caso, por ejemplo, del Instituto de Estudios Almerienses, que viene celebrando desde 1996 unas ya consolidadas Jornadas de Religiosidad Popular que han cumplido este

Campos y Fernández de Sevilla (dir.), La Inmaculada Concepción en España: religiosidad, historia y arte. Actas del Simposium San Lorenzo del Escorial, 2005, San Lorenzo del Escorial, Real Centro Universitario EscorialM. ${ }^{a}$ Cristina, 2005, 2 vols.; José Ruiz Fernández y Valeriano Sánchez Ramos (coords.), La religiosidad popular y Almería. Actas de las IV Jornadas de religiosidad popular. 2004, Almería, Instituto de Estudios Almerienses, 2005, 2 vols.; Françoise Cazal, Amaia Arizaleta y Claude Chauchadis (coords.), Pratiques Hagiographiques dans l'Espagne du Moyen Âge et du Siècle d'Or, Toulouse, Toulouse-Le Mirail Université, 2005, 2 vols.; Juan Aranda Doncel (coord.), La Advocación de las Penas. Actas del I Congreso Nacional, Córdoba, Hermandad de las Penas de Santiago, 2006; Valeriano Sánchez Ramos (coord.), Los mínimos en Andalucía. IV Centenario de la fundación del Convento de Nuestra Señora de la Victoria de Vera (Almería), Almería, Instituto de Estudios Almerienses, 2006; Juan Aranda Doncel (coord.), La advocación de Jesús Nazareno. Actas del Congreso Nacional, Pozoblanco, Hermandad de Jesús Nazareno, 2007; Rafael Retana Rojano (coord.), Historia devocional en la Málaga del siglo XVIII. La Antigua Hermandad del Santo Rosario de Nuestra Señora de los Remedios de la Parroquia de los Santos Mártires, Málaga, Ayuntamiento de Málaga, 2007; Valeriano Sánchez Ramos (coord.), Lux Mundi. La religiosidad popular en torno a la luz. Actas del I Congreso Nacional de Advocaciones de la Luz. Dalías, octubre de 2006, Almería, Instituto de Estudios Almerienses, 2007; Francisco J. Campos y FERnándEZ DE SEvilla (dir.), El culto a los santos. Cofradías, devoción, fiestas y arte. Actas del Simposium San Lorenzo del Escorial, 2008, San Lorenzo del Escorial, Real Centro Universitario Escorial-M. a Cristina, 2008; Jorge Abril Aznar (coord.), Identidades compartidas. Cultura y religiosidad popular en Aragón, Zaragoza, Prensas de la Universidad de Zaragoza, 2009; José Ruiz Fernández y Juan P. VázQuez Guzmán (coords.), Religiosidad Popular. Actas de las V Jornadas. 2007, Almería, Instituto de Estudios Almerienses, 2010; Eliseo SERRAno MARTín (coord), Fábrica de santos: España, siglos XVI-XVII, Jerónimo Zurita, 85 (2010) (Dosier); NoguÉs y CHECA (coords.), La Cultura Sentida. Homenaje al profesor Salvador Rodríguez Becerra; Juan Aranda Doncel (coord.), La devoción a Nuestra Señora del Carmen en la diócesis cordobesa durante los siglos XVI al XVIII. Actas del Congreso Nacional Carmelitano, Córdoba, Diputación de Córdoba, 2013; José Ruiz Fernández y Juan P. VÁzQuez Guzmán (coords.), La religiosidad popular y Almería. Actas de las VI Jornadas de religiosidad popular. 2011, Almería, Instituto de Estudios Almerienses, 2014; Rafael Serrano García, Ángel de Prado Moura y Elisabel Larriba (eds.), Discursos y devociones religiosas en la Península Ibérica, 1780-1860. De la crisis del Antiguo Régimen a la consolidación del Liberalismo, Valladolid, Universidad de Valladolid / Aix Marseille Université, 2014; Juan Aranda Doncel y Ramón de la Campa Carmona (coords.), Regina mater misericordiae. Estudios históricos, artísticos y antropológicos de advocaciones marianas, Córdoba, Eds. Litopress, 2016; Juan ArandA Doncel y Julián Hurtado de Molina Delgado (coords.), San Rafael y el patronazgo de los Santos Mártires en Andalucía. Historia, arte y espiritualidad, Córdoba, Ediciones Litopress, 2016; José A. Peinado Guzmán y M. a del Amor Rodríguez Miranda (coords.), Meditaciones en torno a la devoción popular, Córdoba, Asociación «Hurtado Izquierdo», 2016; Valeriano SÁnchez Ramos (ed.), María, Regina Naturae. Actas del Congreso Mariano Nacional sobre Advocaciones de la Virgen vinculadas a la naturaleza: Historia, arte y cultura. Berja, 20-22 mayo 2016, Berja, Centro Virgitano de Estudios Históricos, 2016; Juan Aranda Doncel (coord.), Los dominicos y la advocación del Dulce Nombre de Jesús en Andalucía, Archidona (Málaga), Archicofradía del Dulce Nombre de Archidona, 2017. 
año su séptima convocatoria ${ }^{12}$. En la Comunidad de Madrid -6 monografías (13,3\%) — cabría mencionar la labor del Instituto Escurialense de Investigaciones Históricas y Artísticas, dependiente del Real Centro Universitario EscorialM. ${ }^{a}$ Cristina; esta institución es la única en el ámbito nacional que, en términos cuantitativos, puede equipararse a las andaluzas en cuanto a interés por el conocimiento y difusión de todo lo que se refiere a la religiosidad ${ }^{13}$. Las restantes 9 monografías se distribuyen entre Castilla-León (4), Aragón (2), Cantabria (1), Comunidad Valenciana (1) y Francia (1).

Ya en 1980, Rodríguez Becerra comenzaba a indagar en la religiosidad popular $^{14}$. En 1985 lo hacía un grupo interdisciplinar coordinado por el sociólogo Pedro Castón ${ }^{15}$. Luego ya, en 1989, vería la luz una de esas obras que, como en cualquier campo del conocimiento, marcan un hito. Me refiero a la coordinada por el historiador modernista Carlos Álvarez Santaló, la antropóloga M. a Jesús Buxó i Rey y el también antropólogo, ya citado, Rodríguez Becerra ${ }^{16}$. Participaban en ella un centenar de autores, llevando a las páginas de los tres volúmenes que la integran lo que, en mi criterio, constituía el más acabado e iluminador compendio de los saberes que en el campo de la religiosidad se tenían cuando concluía la década de 1980. En adelante ya nada sería igual en materia de investigar la historia de las devociones y de desvelar sus múltiples significados. Si bien en la obra las aportaciones eran en gran medida el resultado de estudios realizados sobre Andalucía, en ella tenían también presencia investigaciones realizadas en la práctica totalidad de las regiones españoles —incluso en algunas naciones de la América hispana_, desde la Edad Media hasta la Contemporánea. En sus páginas, como nunca antes, se reflexionaba sobre el propio

12 Dispongo tan solo de la información relativa a los contenidos de las Jornadas: Elementos materiales y culturales de la tradición popular: De cruces y cruceros.

13 Esta institución organizó en 1992 el primer Simposium de San Lorenzo del Escorial, dedicado a la música en el monasterio del Escorial. Desde entonces, bajo la coordinación de Francisco Javier Campos y Fernández de Sevilla, ha venido celebrando uno anualmente, de tal modo que en este 2017 se ha clausurado el vigésimo quinto, bajo el título Religiosidad popular. Cofradías de penitencia. Institucionalizada esta actividad como «Simposium San Lorenzo del Escorial», cada edición aborda un tema con carácter monográfico. Ante la imposibilidad material de incluir en mi trabajo los contenidos de los cuarenta volúmenes que ocupan las actas de los Simposia, he tomado en cuenta, a modo de muestra, tan solo los de tres de ellos. Los contenidos de todos

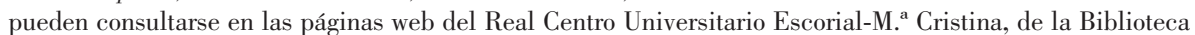
Virtual Cervantes y de Dialnet; no obstante, M. ${ }^{a}$ Paz Alonso Campos ha publicado «Índices generales (19922012)", en Advocaciones Marianas de Gloria. Actas del Simposium San Lorenzo del Escorial, 2012, San Lorenzo del Escorial, Instituto Escurialense de Investigaciones Históricas y Artísticas, 2012, págs. 1.279-1.562.

14 Salvador Rodríguez Becerra y José M. ${ }^{a}$ VázQuez Soto, Exvotos de Andalucía. Milagros y promesas en la religiosidad popular, Sevilla, Argantonio Ediciones Andaluzas, 1980.

15 Pedro Castón Boyer, La religión en Andalucía. Aproximación a la religiosidad popular, Sevilla, Editoriales Andaluzas Unidas, 1985.

16 Álvarez Santaló, Buxó i Rey y Rodríguez Becerra (coords.), La religiosidad popular. 
concepto de «religiosidad popular»; se planteaban cuestiones medulares en cuanto a la teoría, la metodología y las fuentes para su investigación; se atendía a los procesos de construcción social de la religiosidad popular; la casuística estudiada tomaba en cuenta los ámbitos rural y urbano, las múltiples manifestaciones de la religiosidad y sus prácticas sociales, sus funciones más allá de lo estrictamente religioso, su protagonismo en la formación de identidades, sus implicaciones teológicas, jurídicas y políticas, las conexiones entre lo religioso y lo festivo, los cambios y las permanencias, el sincretismo religioso, lo iconográfico, etcétera. En la «Introducción» al primero de los tres volúmenes, Rodríguez Becerra escribía: «Somos conscientes, desde luego, de que los rituales religiosos, como todos los rituales, son polisémicos, y no solo comunican mensajes relacionados con lo sobrenatural, sino también con lo económico, lo social, lo lúdico, lo étnico, la identidad cultural y todo el sistema social» ${ }^{17}$. Por todo esto que, también como nunca antes, se produjera un diálogo en el que participaran voces de tantas disciplinas y que halló continuidad en colaboraciones posteriores, de lo cual dan testimonio las cuarenta y cinco monografías colectivas que constituyen la base bibliográfica de mi estado de la cuestión.

Atiendo lo primero a la cronología objeto de análisis en los artículos contenidos en tales monografías. Si bien, como he dicho, se abarca en ellos desde la Edad Media hasta la Edad Contemporánea, los siglos modernos son los más estudiados, seguidos de los de la contemporaneidad y de los medievales. Dos pueden ser las causas de una mayor presencia de historiadores modernistas en la investigación: una, la nutrida documentación parroquial existente, sobre todo a partir del siglo XVI, el del Concilio de Trento y sus disposiciones respecto a la exigencia de testimoniar documentalmente todo acto sujeto a las funciones y a la jurisdicción del párroco; la otra causa es la orientación de una parte de la investigación modernista, por influencia de la Escuela de Annales, hacia el estudio de las mentalidades, en las que la religiosidad ocupa un espacio propio; el impulso de raíz annaliana en este campo comenzará a dar sus primeros frutos — deudores de la labor promovida por Eiras Roel desde la Universidad de Santiago de Compostela - cuando, recuérdese, se producía el replanteamiento, por influencia de la Antropología, del estudio de algunas de las manifestaciones de la propia religiosidad, entre ellas la devocional.

Tomo ahora en consideración las escalas espaciales de análisis de las que se han servido los investigadores para la observación empírica de sus estudios. Es la escala local la que prima contundentemente, con independencia de la magnitud poblacional de las localidades estudiadas; en gran medida compren-

17 Álvarez Santaló, Buxó i Rey y Rodríguez Becerra (coords.), La religiosidad popular, vol. I, pág. 9. 
sible esto si se tiene en cuenta el esfuerzo que representaría estudiar, aunque fuera nada más que una devoción, en el territorio nacional, incluso en el regional. Tan solo partiendo de lo local, conforme a la propuesta metodológica de Demetrio Brisset de una «investigación concéntrica», pueden abordarse las diversas escalas de lo supralocal ${ }^{18}$; sobre todo, si se trata de dar cuenta de todas y cada una de las variables confluyentes en lo devocional; y, más aún todavía, si ese dar cuenta se hace desde una perspectiva histórica, dependiente en todo momento de la disponibilidad de fuentes.

A escala local, que puede significar tanto una localidad como un fragmento de ella — caso, por ejemplo, de barrios y parroquias en poblaciones de notable tamaño ${ }^{19}$ - se rinde culto a quienes encarnan las devociones nacionales, comenzando por los seres que culminan la jerarquía de lo sagrado: Dios, a través de Jesús, y la Virgen. Serán las muy numerosas advocaciones de esta las que ocupen un lugar preferente en el conjunto de lo investigado ${ }^{20}$; $y$, dentro de estas,

18 Demetrio E. Brisset Martín, «Patronos, fiestas y calendario festivo: una aproximación comparativa», en Carlos Álvarez Santaló, M. ' Jesús Buxó i Rey y Salvador Rodríguez Becerra (coords.), La religiosidad popular, pág. 50 .

19 Véanse Elías Zamora Acosta, «Aproximación a la religiosidad popular en el mundo urbano: el culto a los santos en la ciudad de Sevilla» y Javier Peso Moreno, «Formas de religiosidad popular en el mundo urbano. El culto a San Pancracio», ambos en Carlos Álvarez Santaló, M. a Jesús Buxó i Rey y Salvador Rodríguez Becerra (coords.), La religiosidad popular, vol. I, págs. 527-544 y 545-563; Pilar PÉREz Camarero, «La fiesta de San Pedro en la Calle Alta de Santander: identidad local, devoción popular y cambio frente a permanencia», en José Ruiz Fernández y Juan P. Vázquez Guzmán (coords.), Religiosidad Popular. Actas de las V Jornadas, pp. 393-412. Un caso de análisis sectorial de las devociones en Málaga lo proporciona Marion Reder GADOw: «Advocaciones patronales andaluzas: los Santos Mártires de Málaga», en Juan Aranda Doncel (coord.), Congreso de religiosidad popular en Andalucía, Córdoba, Obra Social y Cultural CajaSur, 1994, págs. 85-100; «Una fiesta para el recuerdo: las fiestas de San Ciriaco y Santa Paula, patronos de Málaga», en Alberto Romero Ferrer (coord.), VI Encuentro de la Ilustración al Romanticismo, 1750-1850. Juego, Fiesta y Transgresión, Cádiz, Universidad de Cádiz, 1995, págs. 351364; «La advocación de la Virgen de los Remedios en Málaga», en Juan Aranda Doncel (coord.), Actas del Congreso Nacional sobre la Advocación de Nuestra Señora de los Remedios. Historia y arte, Córdoba, Diputación Provincial de Córdoba, 1995, págs. 93-110; «Historia de la devoción a la Virgen de los Remedios en Málaga», en Rafael Retana Rojano (coord.), Historia devocional en la Málaga del siglo XVIII, págs. 43-70; «¿Conmemoración política o religiosa? La fiesta de San Luis en Málaga», en Salvador Rodríguez Becerra (coord.), Religión y Cultura, Vol. 1, págs. 637-646; «La devoción a la Virgen de la Victoria de Málaga durante los tiempos modernos», en Valeriano Sánchez Ramos (coord.), Los mínimos en Andalucía. IV Centenario de la fundación del Convento de Nuestra Señora de la Victoria de Vera (Almería), Almería, Instituto de Estudios Almerienses, 2006, págs. 389-410; «El Ayuntamiento de Málaga y su vinculación al Santo Cristo de la Salud. Una devoción histórica», en Juan Aranda Doncel (coord.), La advocación de la Salud, págs. 193-210; «Ayer y hoy de una advocación franciscana en Málaga. La Divina Pastora», en Manuel Peláez del Rosal (dir. y ed.) El Franciscanismo: identidad y poder. Libro homenaje al P. Enrique Chacón Cabello, ofm, Córdoba, Asociación Hispánica de Estudios Franciscanos / Universidad Internacional de Andalucía, 2016, págs. 899-912.

20 Algunas advocaciones han sido objeto de estudio monográfico, caso, por ejemplo, de Aranda Doncel (coord.), Actas del Congreso Nacional sobre la advocación de Nuestra Señora de los Remedios; Aranda Doncel (coord.), Las advocaciones marianas de Gloria; Aranda Doncel (coord.), La Advocación de 
las dedicadas a la Inmaculada Concepción y a la Virgen del Rosario, cuya devoción a esta última se canaliza preferentemente a través de las cofradías bajo su advocación y del rezo del rosario ${ }^{21}$. También Nuestra Señora del Carmen tiene un relativo notable peso entre las devociones de magnitud nacional, aunque de menor entidad; en esta advocación de María hay una dualidad: la de tomarse como mediadora en la liberación de las almas del Purgatorio y como especial protectora de las gentes de la mar ${ }^{22}$. En una dimensión regional, ninguna devoción puede equipararse, en cuanto a merecedora de estudios, a las de la Virgen del Rocío y de la Virgen de la Cabeza, ambas veneradas en Andalucía. En el ámbito de lo local se vive igualmente la devoción a las múltiples advocaciones marianas específicas de la localidad, se trate esta de un pueblo, de una villa o de una ciudad. La devoción a Jesús se concreta sustancialmente en la de su Cuerpo y su Sangre, mediante la magna festividad eucarística del Corpus, y en la del Cristo sufriente de Semana Santa, que se perpetúa a lo largo del año merced a la acción de ciertas cofradías, entre ellas la de la Vera Cruz ${ }^{23}$. Contrasta con la importancia historiográfica y antropológica que ha adquirido ese ciclo litúrgico el otro gran ciclo, el de Navidad, que no ha sido tan atendido por los investigadores $^{24}$.

la Salud; Aranda Doncel (coord.), La Advocación de las Penas; Retana Rojano (coord.), Historia devocional en la Málaga del siglo XVIII. La Antigua Hermandad del Santo Rosario de Nuestra Señora de los Remedios de la Parroquia de los Santos Mártires; SÁnchez Ramos (coord.), Lux Mundi. La religiosidad popular en torno a la luz; Aranda Doncel y Campa Carmona (coords.), Regina mater misericordiae; Sánchez Ramos (ed.), María, Regina Naturae.

${ }^{21}$ Véanse VV. AA., La Orden Concepcionista; Campos y Fernández de Sevilla (dir.), La Inmaculada Concepción en España. Por la especificidad del rezo del rosario como canalizador de la devoción a la Virgen del mismo nombre, pueden verse los trabajos de Carlos J. Romero Mensaque, «Cotidianidad, dinamismo y espontaneidad en la religiosidad popular: el fenómeno de los rosarios públicos en la Sevilla del Barroco», Espacio, tiempo y forma. Serie IV. Historia Moderna, 11 (1998), págs. 215-238; "Génesis e hitos históricos de un acontecimiento de la religiosidad popular europea moderna: el fenómeno rosariano desde la iniciativa clerical a la recreación popular», Revista de Humanidades, 16 (2009), págs. 35-58; La devoción al rosario y sus cofradías en España durante la Modernidad. Siglos XV al XVIII, Salamanca, San Esteban, 2017.

22 Véase Aranda Doncel (coord.), La devoción a Nuestra Señora del Carmen en la diócesis cordobesa durante los siglos XVI al XVIII. Puede consultarse también Antonio Montesino GonZÁlez, La fiesta del Carmen, Revilla de Camargo. Un estudio antropológico sobre religiosidad en Cantabria, Santander, Editorial Límite, 1992; Ramón Maruri Villanueva, «La Virgen del Carmen en las devociones marineras», La Ortiga. Revista cuatrimestral, de arte, literatura y pensamiento, 75-77 (2007), págs. 11-44.

23 Véanse Campos y Fernández de Sevilla (dir.), Religiosidad y ceremonias en torno a la Eucaristía; Sánchez Ramos (coord.), Lux Mundi. La religiosidad popular en torno a la luz; Aranda Doncel (coord.), Los dominicos y la advocación del Dulce Nombre de Jesús; Aranda Doncel (coord.), La Advocación de las Penas; Aranda Doncel (coord.), La advocación de Jesús Nazareno; Francisco J. Campos y Fernández de Sevilla (dir.), Los crucificados, religiosidad, cofradías y arte. Actas del Simposium del Escorial, 2010, San Lorenzo del Escorial, Real Centro Universitario Escorial-M. ${ }^{a}$ Cristina, 2010.

24 Véase Fermín Labarga García, «La piedad popular en el ciclo del Adviento y la Navidad», en José Ruiz Fernández y Juan P. Vázquez Guzmán (coords.), Religiosidad Popular. Actas de las V Jornadas. 2007 [Almería], págs. 11-38. Puede consultarse también Francisco J. Campos y Fernández de Sevilla (coord.), La 
También en lo local se testimonia la devoción a los seres que ocupan el nivel inferior a Jesús y a la Virgen en la jerarquía de lo sagrado. Se trataría de los santos y santas de veneración igualmente nacional, entre los que sobresale el patrón de España, tan caro a los monarcas, Santiago ${ }^{25}$. Y, por último, la devoción a santos y santas que, por su vetustez, rareza u otra circunstancia, su influencia territorial puede llegar a ser mínima o, al menos, limitada a una o a unas muy pocas localidades ${ }^{26}$.

Una devoción que escapa a la jerarquización de los seres sagrados, en tanto que se trata de un concepto, es la que se profesa a las Ánimas del Purgatorio. Su difusión, masiva, no puede entenderse sin la energía y contundencia con que actuó la Iglesia contrarreformista como respuesta radical a la negación del Purgatorio por parte de las Iglesias protestantes. Su estudio ha ocupado y ocupa un lugar de primera magnitud en el territorio de la religiosidad, sobre todo entre quienes investigan en el campo de las cofradías y en el de las actitudes ante la muerte en la España Moderna ${ }^{27}$.

Precisadas la escala espacial de análisis y la cronología preferentes en el estudio de las devociones, queda por ver qué planos de significación se han estudiado. Interesarse por la devoción a un ser sagrado como objeto de conocimiento exige plantear un mínimo de preguntas medulares: cuándo llegó a una localidad, por qué, para qué y cómo evolucionó en el espacio y en el tiempo, puesto que una devoción, producto de la historia, para nada es una realidad estática.

En la España Moderna, como en otras naciones europeas, el orden social que la define es el del Antiguo Régimen, uno de cuyos componentes vertebra-

Natividad. Arte, religiosidad y tradiciones populares. Actas del Simposium, 2009, San Lorenzo del Escorial, Real Centro Universitario Escorial-María Cristina, 2009.

25 Véase VV. AA., Santiago y la Monarquía de España (1504-1788). De ineludible consulta es la monografía de Francisco Márquez Villanueva, Santiago: trayectoria de un mito, Barcelona, Ediciones Bellaterra, 2004. Igualmente, las de Ofelia Rey Castelao, La historiografía del voto de Santiago. Recopilación crítica de una polémica histórica, Santiago de Compostela, Universidade de Santiago de Compostela, 1985; Los mitos del apóstol Santiago, Vigo, Nigra Trea, 2006.

26 Véanse, a modo de ejemplo, Matilde Fernández Montes, «San Audito, mártir de Buitrago» y Valeriano SÁnchez Ramos, «El culto a San Tesifón en Berja (Almería)», en Salvador Rodríguez Becerra (coord.), Religión y Cultura. Actas II Congreso de Religiosidad Popular. Andújar, 1997, Junta de Andalucía / Fundación Machado, Sevilla, 1999, vol. 2, págs. 245-256 y 621-636; María BobadilLa ConesA, «Las romerías a la ermita de San Velastuto en la Ribagorza (Huesca) y la canónica de San Pedro de Taberna», en Carlos Álvarez Santaló, M. Jesús Buxó i Rey y Salvador Rodríguez Becerra (coords.), Religiosidad popular, vol. III, págs. 169-185.

27 Véanse, a modo de ejemplos, Emilio A. Riquelme Gómez, «Las cofradías de ánimas y su 'mapa de la muerte” , Ana M. a JiméNez BARTolomé, «Las hermandades de ánimas: una aproximación al caso de Málaga» y J. Rodríguez Marín, «Las hermandades de ánimas en Málaga: aspectos devocionales y artísticos», en José Ruiz Fernández y Valeriano Sánchez Ramos (coords.), La religiosidad popular y Almería. Actas de las II Jornadas de religiosidad popular, vol. 1, págs. 263-276, 277-304 y 305-330. Sobre la dimensión religiosa de la muerte, es de ineludible consulta en este monográfico el estudio de M. José de la PAscua Sánchez; en cuanto a las cofradías, véase nota.$^{\circ} 2$. 
dores es el corporativismo; es decir, un sistema en el cual el individuo carece de individuación, puesto que lo que le dota de identidad es la pertenencia a un cuerpo — familia, barrio, parroquia, gremio, etcétera-. Un corporativismo, sirviéndome de las aportaciones que hicieron a la teoría sociológica F. Tönnies, É. Durkheim y G. Simmel, traducible en comunitarismo ${ }^{28}$.

Este se halla sólidamente asociado a la fragmentación y débil articulación territoriales, producto, por un lado, de la organización social del espacio en la Edad Media y, por otro, de la insuficiencia y deficiencia de las vías de comunicación, lo cual se traduce en una débil interacción de las comunidades humanas. En el orden de lo simbólico, la también fragmentación de esas comunidades se expresa en términos de particularismo y la subsiguiente conformación de una identidad grupal, afirmando así dialécticamente el «nosotros» frente a «los otros». Además de las múltiples identidades intragrupales existentes dentro de una misma comunidad humana — de género, de edad, de estado civil, de profesión, de estatus, etcétera-, en la sociedad tradicional — la que da carácter a la sociedad de los siglos modernos o antiguorregimental—, la comunidad, cuya vida social la regula un ethos colectivo, se dota, como he dicho, de su propia identidad como grupo. Una identidad construida con elementos diversos, entre los que el religioso, y dentro de este el devocional, constituye uno, además muy vigoroso ${ }^{29}$. Ilustro esto con un caso observado en mis investigaciones y del que habré de servirme, a la vez, para abordar para abordar otras cuestiones.

En el siglo XII, en el extremo occidental de Cantabria, se había configurado ya, en términos político-administrativos, un «Valle», sinónimo de municipio en el lenguaje contemporáneo. Se trataba de un Valle de fronteras oscilantes durante la Baja Edad Media, pero que a partir del siglo Xvi lo constituyen ya

${ }_{28}$ Ferdinand Tönnies, Comunidad y asociación. El comunismo y el socialismo como formas de vida social, Barcelona, Península, 1979 (1. a ed. alemana, 1887); Émile Durkнeıм, La división del trabajo social, Madrid, Akal, 1982 (1. ${ }^{a}$ ed. francesa, 1893); Georg SimmeL, El individuo y la libertad. Ensayos de crítica de la cultura, Barcelona, Península, 1986 (1. a ed. alemana, 1904).

29 Véanse Alejandro Casado Alcalde, Francisco Checa Olmos y Antonio García GonzÁlez, «Reproducción de identidades en la romería del valle del Zalabí (Granada)» y Pedro M. y Antonio Fernández OrteGA, «El santuario del Saliente o la identidad de un pueblo», en Carlos Álvarez Santaló, M. a Jesús Buxó i Rey y Salvador Rodríguez Becerra (coords.), La religiosidad popular, vol. III, págs. 112-127 y 315-326; Eloy GómEZ PELlón, «Religiosidad e identidad: antropología del fenómeno de las devociones en Cantabria» y Mary RosCALES SÁnchez, «El poder de las imágenes religiosas (Prácticas y creencias en torno a Nuestra Señora la Bien Aparecida», en Ramón Maruri Villanueva, (ed.), La Iglesia en Cantabria, págs. 461-497 y 499-521; Salvador Rodríguez Becerra, «El proceso de construcción de identidades con símbolos religiosos en ciudades de Andalucía. El caso de Andújar (Jaén)», en David González Cruz (ed.), Ritos y Ceremonias en el Mundo Hispano durante la Edad Moderna. págs. 227-244; José I. Gómez Zorraquino, «Los santos patronos y la identidad de las comunidades locales», en Eliseo Serrano Martín (coord.), Fábrica de Santos, págs. 39-74; Pablo J. LoRITE Cruz, «La curiosa unidad religiosa de Sierra Mágina mediante los crucificados patronales», Sumuntán: anuario de estudios sobre Sierra Mágina, 31 (2013), págs. 145-164. 
catorce núcleos de población o «concejos», que son los que en la actualidad forman el Ayuntamiento del mismo nombre. Val de San Vicente, atendiendo a su historia desde esa centuria, formaba una unidad compacta, testimoniada de manera incuestionable en el siglo XVIII según la la información proporcionada por el Catastro de Ensenada: unidad en lo económico —-dominio de la actividad agropecuaria_, en lo social — masiva presencia de campesinos, junto a una minoría de notables locales, no precisamente distinguidos por sus disponibilidades económicas—, en lo jurídico-político — señorío de los duques del Infantado, que gobernaban un amplio territorio desde la villa de Potes (LiébanaCantabria) — y en lo eclesiástico — hasta 1754, dependiente del arzobispado de Burgos, y, en adelante, del obispado de Santander-.

Sin embargo, desde el punto de vista devocional, Val de San Vicente constituía un microcosmos. La segmentación de las devociones en materia de patronos locales, que son los que, por uno u otro motivo, eligen motu proprio las comunidades para ponerse bajo su especial protección, era tal que ni uno solo de los catorce pueblos tenía el mismo. Cuestión bien diferente es que las advocaciones bajo las cuales se hallaran los templos parroquiales fueran también diferentes — que lo eran-, puesto que las eligen quienes promueven y costean la construcción y dotación de ellos, mayoritariamente la autoridad eclesiástica, si bien, desde que, en el marco del régimen señorial, se implanta la institución de la «iglesia propia», podían serlo, en su condición de «patronos», también los señores laicos o eclesiásticos e, incluso, las propias comunidades ${ }^{30}$. Cómo no recordar en este caso a Ernest Gellner cuando subraya que en las sociedades tradicionales no existe un leguaje compartido, sino una «multiplicidad de jergas» ${ }^{31}$. En el caso visto, se trataba de catorce jergas dentro de un territorio que ocupaba $51 \mathrm{~km}^{2}$ y se hallaba habitado por una población, en el siglo XVIII, de en torno a 2.500 personas.

Para comprender lo que subyace a esta realidad, me sirvo, por su operatividad, de tres conceptos manejados por William Christian en su estudio antropológico del Valle del Nansa (Cantabria); tales conceptos son los de «imágenes de devoción», «devoción generalizada» —unas y otra en permanente tensión- y «territorio de gracia» ${ }^{32}$. De las «imágenes de devoción» y de la «devoción generalizada» dice:

\footnotetext{
30 Véase Esther Peña Bocos y Elisa Álvarez Llopis, «La génesis de la organización eclesiástica en el territorio regional», en Ramón Maruri Villanueva (ed.), La Iglesia en Cantabria, págs. 112-118.

31 Ernest GelLner, Naciones y nacionalismo, Madrid, Alianza Editorial, 2001, passim.

32 Christian, Religiosidad popular. Estudio antropológico en un valle español, passim; de ineludible consulta es también su Religiosidad local en la España de Felipe II.
} 
Los dos tipos de advocaciones sagradas [...] representan dos extremos en la Iglesia: la Iglesia local y la Iglesia universal. En realidad, parece que hasta hace poco el constante intento de la Iglesia universal de integrar la comunidad local en la comunidad de la cristiandad por medio de las devociones generalizadas, fue una batalla continuamente perdida, ya que las comunidades locales se apropiaban de las devociones generalizadas para uso local como imágenes de devoción ${ }^{33}$.

Ciertamente, Christian aplica ambos conceptos a las advocaciones, es decir, a «una variante de una imagen sagrada», por excelencia la Virgen, cuya apropiación por la comunidad local se realiza complementando el sustantivo Virgen o Nuestra Señora de con el nombre de la localidad:

[...] si la imagen se considera especial, si ha llegado a tener un territorio de gracia, no es, entonces, meramente Nuestra Señora del Carmen [Iglesia universal], sino Nuestra Señora del Carmen de Cosío, o de Sopeña, o de Nava de Santullán [Iglesias locales]. Esto es, llega también a ser única y diferente de otras imágenes de Nuestra Señora del Carmen. Su exclusividad se le confiere por su localización. La misma localización, impregnada por una tradición de culto, confiere a menudo un territorio de gracia a una imagen ${ }^{34}$.

No obstante, considero que el concepto «imagen de devoción», aplicable a la imagen devocional individuada mediante un nombre local, puede ser del todo extrapolable a cualquier imagen sagrada no individuada nominalmente. En otras palabras, estimo que, dando amplitud a su campo semántico, «imagen de devoción» es susceptible de ser entendida como la imagen o imágenes sagradas amparantes de una comunidad que esta «siente» suya o suyas, otra manera, ciertamente que implícita, de apropiarse de una «devoción generalizada». Se trataría de «otra» forma de apropiación del ser sagrado por parte de la comunidad local, una proyección, en palabras de R. Williams, de las «estructuras del sentimiento», religioso en este caso $^{35}$.

33 Christian, Religiosidad popular. Estudio antropológico en un valle español, pág. 68. La dialéctica entre Iglesia universal e Iglesia local se expresaba igualmente en otras manifestaciones religiosas, tanto en España como en otras naciones católicas; puede verse al respecto John Bossy, «Controriforma e popolo nell'Europa católica», en M. Rosa (coord.), Le origini dell'Europa moderna, Bari, De Donato, 1977, págs. 281-308.

34 Christian, Religiosidad popular. Estudio antropológico en un valle español, pág. 67.

35 Ver Raymond Williams, El campo y la ciudad, Barcelona, Paidós Ibérica, 2001, passim. Otras formas de apropiación se tratan en Ramón Maruri Villanueva, «Los santos de la comunidad. devociones religiosas en la Cantabria occidental (siglos XVIII-XIX)», en Rafael Serrano García, Ángel de Prado Moura y Elisabel Larriba (eds.), Discursos y devociones religiosas, págs. 181-183. 
Del tercero de los conceptos aportados por Christian, el de «territorio de gracia» de un ser sagrado, dice este autor que constituye una unidad geográfica y que para las gentes que habitan en ella «viene a simbolizar el paisaje y las actividades en las que se basa la identidad», considerando constituye «un punto de compromiso en el paisaje entre el grupo humano, la tierra y los poderes que influyen en el éxito de las empresas del grupo» ${ }^{36}$. Christian aplica «territorio de gracia» al de los santuarios y a los de otros lugares sagrados con fuerza de atracción de gentes de diversas localidades. Sin embargo, al igual que propuse líneas arriba la pertinencia de extrapolar el concepto «imagen de devoción» a devociones generalizadas no individuadas por el nombre de una localidad, del mismo modo puede aplicarse «territorio de gracia» al espacio en que se asienta la comunidad a la que el ser sagrado ampara. Porque, incluso, el mismo santo en comunidades distintas, por próximas que estén, no genera necesariamente una identidad común entre ellas: el ser sagrado amparante de la comunidad genera exclusivamente una identidad «local».

En el mundo de las devociones locales, que, según vimos, poseían la hegemonía devocional en la España Moderna, un rasgo de apropiación de las devociones generalizadas es, como he comentado, complementar el nombre del ser sagrado. Un nombrar cuántas veces asociado no tan solo a la denominación de la localidad a la que ese ser sagrado protege, en su condición de «patrono», sino a un lugar concreto de la localidad cuya toponimia remite a la naturaleza, mayoritariamente a la orografía y a la vegetación, y también mayoritariamente asociada a la Virgen: (del) llano, (del) somo, (del) otero, (de la ) linde, (del) vado, (del) hayedo, (del) endrinal, (del) robledal, (del) encinal, (de la) castañera, etcétera. Se trataría de una hierofanía, de una manifestación, en términos de leyenda, de lo sagrado en el paisaje físico, quedando este, pues, sacralizado. Sobre el vínculo que se establece entre ser sagrado, comunidad humana y espacio, afirma Honorio Velasco:

[...] la delimitación de lugar es tan concreta, la comunidad tan determinada, que el ser sobrenatural recibe una denominación concreta. Aun reconociendo que la persona sobrenatural tiene poder sobre toda la tierra, la leyenda, de hecho, focaliza ese poder a un punto concreto, a una tierra determinada, a una comunidad determinada. Es una forma de otorgar concreción al propio ser sobrenatural ${ }^{37}$.

36 Christian, Religiosidad popular. Estudio antropológico en un valle español, pág. 65.

37 Honorio M. Velasco, «Las leyendas de hallazgos y de apariciones de imágenes. Un replanteamiento de la religiosidad popular como religiosidad local», en Carlos Álvarez Santaló, M. Jesús Buxó i Rey y Salvador Rodríguez Becerra (coords.), La religiosidad popular, vol. II, pág. 402. Las conexiones entre lo sagrado y la naturaleza han merecido un tratamiento monográfico en Sánchez Ramos (ed.), María, 
Cuestión también de irrenunciable planteamiento es la de indagar el motivo por el cual un ser sagrado fue, en un determinado momento, tomado como protector de la comunidad. Esto no exigiría gran esfuerzo en el caso, cuando de taumaturgia se trata, de devociones a santos y santas tipificados o «especializados» en determinado tipo de protección. Me refiero fundamentalmente, dado el carácter instrumental que en el Antiguo Régimen tiene la religión —elegir un ser sagrado como modelo de virtudes a imitar, ideal de la jerarquía eclesiástica, y hasta de la política (¿Cómo entender en una realidad social penetrada de sacralidad que el orden social fuera autónomo respecto al orden moral?), era un plato demasiado exquisito para el paladar de las comunidades en la sociedad del Antiguo Régimen, dado su carácter mayoritariamente rural y su estructural precariedad económica一, a la búsqueda de santos protectores contra las enfermedades de las personas y de los animales, los conocidos como santos «terapeutas»; algunos de ellos tan canónicos en la Cristiandad occidental como San Sebastián, San Roque o San Lázaro en materia de epidemias de peste y otras, y San Antonio Abad / San Antón, preferentemente, en cuanto a los animales; y a proveerse también de santos y santas protectores contra desastres naturales, tales como tormentas, lluvias torrenciales, sequías o plagas ${ }^{38}$.

Regina Naturae. Véase también Roberto SÁnchez GaRRido, «La sacralización del medio natural: la Virgen de los Lirios y el parque natural de la Sierra del Carrascal de la Font Roja», en José Ruiz Fernández y Juan P. Vázquez Guzmán (coords.), La religiosidad popular y Almería. Actas de las V Jornadas de religiosidad popular, págs. 159-172. Un planteamiento amplio de las relaciones sacralidad-espacio y sus manifestaciones, en José L. Puerto, Expresiones de religiosidad popular, Valladolid, Universidad de Valladolid, 2010, págs. 11-90.

38 En la bibliografía que he manejado hay una amplia casuística al respecto; a modo de ejemplos: González Alcantud y Rodríguez Becerra (eds.), Creer y curar: la medicina popular; José I. de Arana AmuRRIO, «Devoción a los santos sanadores», en Francisco J. Campos y Fernández de Sevilla (dir.), Religiosidad popular en España, vol. I, págs. 581-606; Laura DíAz MEJías, «Las prácticas religiosas en la medicina popular del siglo XviII», en José A. Peinado Guzmán y M. ${ }^{a}$ del Amor Rodríguez Miranda (coords.), Meditaciones en torno a la devoción popular, págs. 114-128; Martí Gelabertó Vilagran, «La liturgia católica: bendiciones y exorcismos en la Cataluña del siglo XVI», en Eliseo Serrano Martín (coord.), Muerte, religiosidad y cultura popular, págs. 199-221 (De GelaberTó, por la amplitud de la perspectiva, puede consultarse $\mathrm{La}$ palabra del predicador. Contrarreforma y superstición en Cataluña (siglos XVII-XVIII), Universidad Autónoma de Barcelona, 2003 (Tesis doctoral, en Red); Ángel Aponte Marín, «Conjuros y rogativas contra las plagas de langosta en Jaén (1670-1672) », en Carlos Álvarez Santaló, M. Jesús Buxó i Rey y Salvador Rodríguez Becerra (coords.), Religiosidad popular, vol. II, págs. 554-562; Francisco J. Delicado Martínez, «Iconografía, arte y devoción popular en torno de los Santos de la piedra Abdón y Senén, en el antiguo Reino de Valencia», en Francisco J. Campos y Fernández de Sevilla (dir.), El culto a los santos, págs. 315-332 [Protectores contra el granizo y el pedrisco]. Roldán Jimeno Aranguren, «San Gregorio Ostiense de Navarra. Abogado contra plagas agrícolas y males del oído», en Francisco J. Campos y Fernández de Sevilla (dir.), Religiosidad popular en España, vol. I, págs. 307-332. Por la diversificación de los contenidos pueden consultarse Armando Alberola y Jorge Olcina (eds.), Desastre natural, vida cotidiana y religiosidad popular en la España moderna y contemporánea, Alicante, Universidad de Alicante, 2009; Juan C. SAnz Laroca, Las respuestas religiosas ante las plagas del campo en el XVII español. El hombre frente a la naturaleza, Editorial Académica, 2012. Aunque referido a Asturias, una útil guía de santos terapeutas, por su extrapolación a 
En sociedades poseedoras de un imaginario colectivo en el que tiene una vigorosa presencia la indefensión de sus gentes ante mil y un peligros que no entienden en términos de ciencia, necesariamente se instala la creencia. Ante cualquiera de esos peligros para la comunidad, ante «todo infortunio colectivo», como expresa Christian, había que dar «una respuesta colectiva», preferentemente las rogativas ${ }^{39}$. Por lo general, salvo que la comunidad dispusiera de un santo «especializado» en cuestión de epidemias o de catástrofes naturales, se procesionaba — conforme imponía el ritual de las rogativas- el ser sagrado amparante de la comunidad. Cuando esta poseía más de un patrono, lo cual era característico de las ciudades y de los grandes núcleos de población, solía sacarse en procesión el más asociado a la contingencia que había dado lugar a la rogativa; o, cumpliendo disposiciones de la Monarquía, servirse del prescrito para implorar el auxilio divino en ayuda de determinadas empresas, desde un «feliz parto» de la reina de turno hasta un triunfo en los campos de batalla ${ }^{40}$.

Y no se puede olvidar la cuestión de las devociones a santos protectores no de la comunidad, sino de las personas a título individual, ciertamente de problemático conocimiento desde el punto de vista de las fuentes. A Johan Huizinga debemos el desvelamiento de las causas de la especialización de los santos y santas, surgida en lo que él conceptualiza como «el otoño de la Edad Media»; confluyen en este dos circunstancias determinantes: por un lado, la indefensión de las gentes ante un cúmulo de adversidades políticas, económicas, sociales y demográficas que no comprende, salvo en clave de castigo divino por los pecados cometidos por toda la Cristiandad; y, por otro lado, la acción del clero, sobre todo el regular, que fue predicando un Dios cada vez más y más terriblemente alejado del hombre -Deus otiosus, absconditus—, lo cual lleva a las gentes a crear un panteón de santos y santas mediadores próximos — digamos, familiares-, sanadores y protectores contra cualquier tipo de peligro para el cuerpo y para el alma ${ }^{41}$.

otros ámbitos territoriales, es la que proporciona Joaquín Fernández García, Curanderos y santos sanadores. Curanderismo y medicina popular en Asturias, Oviedo, Grupo Editorial Asturiano (GEA), 1996.

39 Christian (Jr.), Religiosidad local en la España de Felipe II, pág. 213.

40 Una ilustrativa casuística al respecto puede verse en Antonio L. Cortés PeÑa, «Dos siglos de rogativas en Baza (1568-1768)», Iglesia y cultura en la Andalucía moderna. Tendencias de la investigación, estado de las cuestiones, Armilla, Proyecto Sur de Ediciones, [1995], págs. 269-302. Pueden verse también APONTE MARín, «Conjuros y rogativas contra las plagas de langosta en Jaén (1670-1672)»; Tomás Peris Albentosa, «La religiosidad instrumental comunitaria en la ribera del Júcar durante los siglos XVI-XVIII. El ejemplo de las rogativas», en Armando Alberola y Jorge Olcina (eds.), Desastre natural, vida cotidiana y religiosidad popular, págs. 335-389. Se tratan también las rogativas en algunos de los estudios citados en la nota n. 39 .

${ }^{41}$ Ver Johan Huizinga, El otoño de la Edad Media. Estudios sobre la forma de la vida y del espíritu durante los siglos XIV y XV en Francia y en los Países Bajos, Madrid, Alianza Editorial, 1984, págs. 234-248 
Que lo local, reitero, fuera el ámbito territorial por excelencia de la concreción de las devociones y con mayor densidad de significados en la España del Antiguo Régimen, no quiere decir que todo comenzara y terminara ahí. Había devociones a seres sagrados — «las imágenes de devoción» de que habla Christian- cuya influencia trascendía dicho ámbito. Había ermitas, pero sobre todo santuarios, que, por diversos motivos, atraían a personas ajenas al lugar donde se hallaban emplazados. Entramos con esto en la dimensión supralocal, que podía abarcar desde la comarca hasta la propia nación, aunque esta última, como afirmé, representaba una magnitud excesiva para las gentes de los siglos modernos. Era en la comarca y en la propia provincia, o, aunque raramente, en provincias limítrofes, donde con preferencia se vivía lo supralocal, dotando a quienes acudían a ermitas y santuarios de una identidad también supralocal, renovable cada año en la celebración religiosa y romera del «día del santo» ${ }^{42}$; en este sentido, Christian afirma: «Las ceremonias del santuario constituyen afirmaciones sociales tanto como religiosas, reafirmaciones de identidad y de solidaridad $»^{43}$.

Los orígenes de ermitas y santuarios con mucha frecuencia están relacionados con leyendas sobre supuestas apariciones de la Virgen, o con hechos también supuestamente extraordinarios ${ }^{44}$. La tipología de las apariciones responde,

(1. a ed. holandesa, 1919). Además de santos y santas de devoción universal, como, por ejemplo, San Blas, Santa Apolonia, Santos Cosme y Damián o San Vito, en mi base de datos tengo recogidas, entre otras muchas, devociones a santos y santas protectores contra los más insólitos reveses: la calvicie (San Canuto Lavard), los atragantamientos (San Lupo), los celos (Santa Isabel de Portugal), la pérdida de las llaves de casa (Santa Zita), las plagas de ratones, y, por tanto, protectora de los gatos (Santa Gertrudis de Nivelles), la impaciencia (San Paulino de Nola), etcétera.

42 Un expresivo caso, en Casado Alcalde, Checa Olmos y García González, «Reproducción de identidades en la romería del valle del Zalabí (Granada)», págs. 112-127. Pueden verse igualmente otros trabajos citados en la nota n. ${ }^{\circ} 30$.

43 Christian, Religiosidad popular. Estudio antropológico en un valle español pág. 68; refiriéndose a Obeso, un pueblo del Valle del Nansa, ha observado cómo sus gentes encargaban misas de difuntos ya en los siglos XVII y XVIII en santuarios más o menos alejados de esa localidad, como eran los de Nuestra Señora de la Velilla y Nuestra Señora del Brezo, ambos en León, Nuestra Señora de Covadonga, Asturias, o Santo Toribio de Liébana y Nuestra Señora de Las Caldas, en Cantabria; específicos del valle del Nansa y su entorno eran los de Nuestra Señora de la Peña (Celis), El Cristo de Bielva (Bielva), Nuestra Señora de la Luz (Peña Sagra), Nuestra Señora del Carmen (Cosío) y Nuestra Señora del Llano (Obeso); otros santuarios ejercían atracción tan solo, en el mejor de los casos, sobre las aldeas vecinas, pues «son básicamente márgenes locales que actúan, en los momentos de mayor popularidad, como protectoras del racimo de pueblos que comprende el Valle», págs. 73-77, 84-87, 90 y 92.

44 «Esta clase de leyendas, fundantes de un lugar de culto y de su territorio de gracia, administrados por el correspondiente Santuario, parecen formar parte de una configuración constante que se da en este tipo de sucesos, en la que el núcleo narrativo básico normalmente suele responder al siguiente patrón normativo: 1) Una Virgen se aparece a unos pastores que comunican a todo el pueblo, o bien a las personas más notables (alcalde, cura, etc.), la noticia de su hallazgo. A partir de ese momento, vecinos y representantes eclesiásticos deciden, o bien levantar un altar en el lugar en que aparece la figura divina, o bien trasladarla a la iglesia 
en sus rasgos generales, a un patrón fijado, por lo general, en los siglos XV y XVI: apariciones en árboles, en grutas, en caudales de agua, o enterradas, mayoritariamente en el espacio rural; aunque también el fenómeno aparicional no es ajeno al mundo urbano, si bien esto parece hallarse ligado más a la contemporaneidad $^{45}$.

A ermitas y a santuarios se acudía, como ya comenté, desde esa concepción instrumental que se tenía de la religión para solicitar favores, con preferencia relativos a la salud y a la protección frente a situaciones de riesgo que podían poner en peligro la vida de las personas. Testimonios palmarios de esto son los todavía hoy contemplables exvotos en muchas de esas ermitas y santuarios; en una economía donativa, característica de las sociedades tradicionales, los exvotos —al igual que las limosnas, las velas y otras ofrendas- representarían el «contra don» por el «don» o favor recibido ${ }^{46}$.

Concluyo subrayando lo que, en mi criterio, constituyen en la actualidad los dos grandes retos que tiene ante sí el historiador de las devociones religiosas en la España Moderna. Ni uno ni otro tienen que ver con lo conceptual ni con lo metodológico, puesto que la Historia, enriquecida con las aportaciones de la

parroquial del pueblo. 2) En un elevado número de casos, la imagen muestra su resistencia a ser trasladada a otro lugar que no sea el de su originaria aparición. 3) Con motivo del suceso extraordinario se decide la erección, en el lugar del milagro, de una capilla, ermita o santuario», Roscales Sánchez, «El poder de las imágenes religiosas», pág. 500. Véanse también por lo que atañe al modelo de estructura narrativa de las leyendas, VELASCO, «Las leyendas de hallazgos y de apariciones de imágenes. Un replanteamiento de la religiosidad popular como religiosidad local», págs. 401-410; sobre la relación entre orígenes y leyendas en las fundaciones de algunos santuarios, puede consultarse Francisco Tejada Vizuete, «Apariciones y santuarios marianos en la baja Extremadura. Fuentes documentales y bibliográficas», en Carlos Álvarez Santaló, M. ${ }^{\text {a }}$ Jesús Buxó i Rey y Salvador Rodríguez Becerra (coords.), Religiosidad popular, vol. I, págs. 308-323. Salvador Rodríguez BecerRA, «Leyendas de apariciones marianas en Andalucía», en José Reina Macías (coord.), Actas del VIII Encuentro Provincial de Investigadores Locales. Casa de la Provincia, Sevilla, 3 y 4 de junio de 2011, Sevilla, Diputación de Sevilla, 2011, págs. 49-66. De ineludible consulta es Christian (Jr.), Apariciones en Castilla y Cataluña, passim.

45 Véase M. ${ }^{a}$ Josefa Roma Riu, «Centralidad-marginalidad, ortodoxia-heterodoxia. Una aproximación al fenómeno de las apariciones urbanas», en Carlos Álvarez Santaló, M. J Jesús Buxó i Rey y Salvador Rodríguez Becerra (coords.), La religiosidad popular, vol. I, págs. 517-526.

46 Véase Antonio Montesino GonzÁLEz, «"El que recibe a dar se obliga” (la economía moral del don como sistema productor para una economía para vivir», Cuadernos de Campoo, 32 (2003). A modo de ejemplos, véanse, entre otros, Rodríguez Becerra y Vázquez Soto, Exvotos de Andalucía. Milagros y promesas en la religiosidad popular; también los estudios recogidos en el Capítulo IX «Santuarios y exvotos» de la monografía de Álvarez Santaló, Buxó i Rey y Rodríguez Becerra (coords.), La religiosidad popular, vol. III, págs. 211445; igualmente Antonio M. Nogués Pedregal, «Aportación a la religiosidad popular en El Puerto de Santa María: los exvotos a la patrona», en Salvador Rodríguez Becerra (coord.), Religión y Cultura, vol. 2, págs. 229244; Salvador Andrés Ordax, «La expresión artística de los 'exvotos' y los 'cuadros de santuarios'» y Justo Romero Torres, «Exvotos andaluces: la manifestación de lo sagrado y lo estético en la religiosidad popular», en Francisco J. Campos y Fernández de Sevilla (dir.), Religiosidad popular en España vol. II, págs. 7-28 y 2950. Dada la nutrida nómina de estudios dedicados a santuarios y ermitas, sugiero la consulta individualizada de la base bibliográfica que he manejado. 
Antropología, dispone ya de un sólido y más que contrastado bagaje como para dirigir al mundo devocional una mirada compleja.

Uno de los retos es articular todo lo que se ha ido conociendo de manera sectorial y fragmentaria en los innumerables estudios de carácter local.

El otro reto es indisociable de este. Se trata de situarse en la escala supralocal, una atalaya magnífica para ampliar el horizonte del conocimiento sobre las devociones, puesto que el espacio se agranda y la mirada se ensancha. Modelos analíticos a seguir ya existen, sea lo supralocal una comarca, una provincia, una región o un obispado ${ }^{47}$.

Aceptar ambos retos supondría precisar cuántas poblaciones participan de las mismas devociones, por qué se implantaron en ellas, por qué vías lo hicieron y si fue consecuencia de un proceso programado, o, por el contrario, surgieron en tiempos y circunstancias diferentes. La casuística al respecto es plural. En primer lugar, la decisión de las propias comunidades, que buscan, en función de sus intereses más vitales, dotarse de los seres sagrados más eficaces. En segundo lugar, el movimiento misional puesto en marcha en las décadas finales del siglo XVI y acentuado en el XVII como respuesta de la Iglesia tridentina o contrarreformista a la iconoclastia de las corrientes reformadoras surgidas a raíz de la ruptura provocada por Lutero en la Cristiandad occidental; misionar es indisociable del clero regular —a los franciscanos se debió el fomento de las devociones a la Inmaculada Concepción, a la Madre de Dios sufriente, caso de Nuestra Señora de la Soledad o de Nuestra Señora de los Dolores, y a las Ánimas del Purgatorio, del mismo modo que los dominicos propiciaron la devoción a Nuestra Señora del Rosario y el rezo de este; devociones en cuyo fomento y perpetuación se mostrarían imprescindibles, además de los predicadores, las cofradías y las hermandades-. En tercer lugar, agentes promotores o transmisores de devociones eran también la autoridad episcopal, los monarcas, miembros de la nobleza, integrantes de sectores profesionales e individuos sin más, entre los que cabría destacar a quienes, en migraciones

47 En cualquiera de las monografías colectivas de las que me servido existen casos de tales modelos; a modo de ejemplo de cada uno de ellos, prescindiendo, por lo profuso, de las devociones locales, véanse: David LóPEz VIERA, «El Cristo de la Guadaña de Gibraleón: una devoción comarcal», en David González Cruz (ed.), Religiosidad y costumbres populares en Iberoamérica, págs. 293-298; Maruri Villanueva, «Los santos de la comunidad», págs. 163-196; Roberto J. LópEz, «Devociones y cultos marianos en Galicia durante la Edad Moderna», en David González Cruz (ed.), Religiosidad y costumbres populares en Iberoamérica, págs. 49-98; Salvador Hernández González. «Advocaciones de la naturaleza en las leyendas de apariciones marianas del antiguo Arzobispado de Sevilla» y Manuel F. Matarín Guil. «Dos advocaciones marianas de naturaleza en la provincia de Almería: la Virgen de la Fuensanta y la de la Cueva Santa», en Valeriano Sánchez Ramos, María, Regina Naturae, págs. 199-209 y 498-506; Domingo L. GonzÁLEz Lopo, «Onomástica y devoción. La difusión de nuevos cultos marianos en la Galicia meridional durante los siglos XVIII y xix: el Obispado de Tuy», Obradoiro de Historia Moderna, 1 (1992), págs. 165-184. 
dentro del territorio nacional, o allende este, actuaban, en itinerarios de ida y vuelta -incluyo aquí lo que pudo representar la difusión de devociones derivada del peregrinaje por el camino de Santiago—, como agentes generadores de identidades supralocales y de interculturalidad. En cuarto lugar, hay que tomar en cuenta a individuos o a familias llegadas a una localidad y avecindadas en ella portando la devoción a un ser sagrado cuya imagen, situada, por ejemplo, en una ermita, en una capilla o en cualquier espacio público, con el paso del tiempo podía llegar a ser objeto del fervor común ${ }^{48}$. Saber de todo esto

48 Véanse Juan Aranda Doncel, «El Beato Diego José de Cádiz y las misiones populares de la hermandad cordobesa de la Esperanza y Santo Cielo de la Salvación de las Almas», en Manuel Peláez del Rosal (dir.), El Franciscanismo. Identidad y poder, págs. pp. 271-286; Elías DE Mateo Avilés, «Las santas misiones en la diócesis de Málaga durante el siglo XIX», en Carlos Álvarez Santaló, M. Jesús Buxó i Rey y Salvador Rodríguez Becerra (coords.), La religiosidad popular, vol. II, págs. 174-189; un amplio tratamiento de las misiones, en Francisco L. Rico Callado, Las misiones interiores en la España de los siglos XVII-XVIII, Biblioteca Virtual Cervantes, 2003. Un caso de devoción decretada por la autoridad episcopal a finales del siglo xviII, en Maruri Villanueva, «Los santos de la comunidad», págs. 173-174. Un caso de implantación de una devoción por tierras de Granada y Almería a raíz de sofocar don Juan de Austria la sublevación de los moriscos de las Alpujarras, en José M. Martínez LóPEz, «Religiosidad, diversión y aplicación didáctica de las fiestas. El caso de San Sebastián», en José Ruiz Fernández y Valeriano Sánchez Ramos (coords.), La religiosidad popular y Almería. Actas de las I Jornadas de religiosidad popular, págs. 401-419; pueden consultarse también sobre las conexiones entre los poderes político y social y las devociones, Paula Bellido Gómez y Rafael Retana Rojano, «Influencia regia en la extensión de la devoción del rosario en Málaga en la segunda mitad del siglo XVII», en Marion Reder Gadow (coord.), Actas del Congreso sobre la Andalucía de finales del siglo XVII, Cabra, Ayuntamiento de Cabra, 1999, págs. 345-352; VV. AA., Santiago y la Monarquía de España (1504-1788); Pedro J. Moreno DE Soto, «El conde de Ureña, los dominicos y la cofradía del Dulce Nombre de Jesús», en Juan Aranda Doncel (coord.), Los dominicos y la advocación del Dulce Nombre de Jesús en Andalucía, págs. 223-256; Pedro J. Moreno de Soto, Dogma, poder e ideología: la Casa de Osuna y la devoción a la Inmaculada Concepción, Osuna, Amigos de los Museos de Osuna, 2006. M. ${ }^{a}$ Justina Sarabia Viejo e Isabel Arenas Frutos, «Andaluces en Zacatecas (México), 1700-1750. Sus devociones y ritos ante la muerte» y Domingo L. GonZÁLEZ Lopo, «Migraciones de santos: el intercambio de devociones entre Galicia y América en la época colonial (ss. XVII-XIX)», en David González Cruz (ed.), Ritos y Ceremonias en el Mundo Hispano durante la Edad Moderna. págs. 209-226 y 297-313; Fermín Labarga García, «Un ejemplo del trasvase artístico y religioso desde la ciudad de Sevilla a Logroño a finales del siglo XVII", en Marion Reder Gadow (coord.), Actas del Congreso sobre la Andalucía de finales del siglo XVII, págs. 295-310; Fermín Labarga García, «La devoción a la Virgen de Valvanera en América», en Casimiro Somalo (coord.), El viaje de los sueños. Emigración riojana a América, Gobierno de La Rioja / Fundación CajaRioja, Logroño 2006, págs. 116-141; Álvaro PAstor TorRes, «Nuestra Señora de Roca Amador: una devoción francesa en la Sevilla moderna», en Francisco J. Campos y Fernández de Sevilla (dir.), Religiosidad popular en España, vol. I, págs. 401-426. Sandra DE Arriba Cantero, «De artesano a artista: instrumentalización de la imagen Josefina en el ámbito gremial», en Francisco J. Campos y Fernández de Sevilla (dir.), El culto a los santos, págs. 521-532; Margarita GIL Muñoz, La vida religiosa de los mareantes. Devociones y prácticas, Madrid, Ministerio de Defensa, 2005; Eduardo Morales Solchaga, «Cofradías bajo la advocación de San Lucas, especial protector de los pintores en España. El caso de Navarra», en Francisco J. Campos y Fernández de Sevilla (dir.), El culto a los santos, págs. 829-846; Isidoro Moreno, La antigua hermandad de los negros de Sevilla. Etnicidad, poder y sociedad en 600 años de historia, Sevilla, Universidad de Sevilla, 1997. Pilar Pérez Camarero, «Las hornacinas de devoción privada en Marbella», en Salvador Rodríguez Becerra (coord.), Religión y Cultura, vol. 2, págs. 575-590; Rosario Camacho MaRTínEz, «Camarines y capillas callejeras en la arquitectura barroca malagueña», en Francisco J. Campos y 
permitiría trazar geografías de las devociones y practicar la historia comparada, siempre iluminadora ${ }^{49}$.

Por último, el estudio de una devoción en el tiempo largo desvelaría su dinámica en la medida en que no siempre mantiene la misma intensidad desde la perspectiva del fervor de los devotos — precisos indicadores de esto bien pudieran ser los libros de registro de miembros de cofradías y hermandades, o de limosnas y donaciones a ermitas y santuarios-, hasta el punto, por causas diversas, de que la devoción pudiera ser sustituida por otra ${ }^{50}$. Del mismo modo, esa dimensión del tiempo podría hablarnos, en términos de cambios y permanencias, de redefiniciones de una devoción, en cuanto a su significado y función y en cuanto a su celebración desde el observatorio de lo estrictamente lúdico ${ }^{51}$. Ciertamente, fijar en el tiempo y en el espacio tales redefiniciones plantea al

Fernández de Sevilla, Religiosidad popular en España, vol. II, págs. 329-350. Conexo con algunas de estas cuestiones, aunque se refiera a la Virgen, es el estudio de Salvador Rodríguez Becerra, «La Virgen María en Andalucía: aproximación a los procesos de creación, difusión e institucionalización de las devociones marianas», en David González Cruz (coord.) Vírgenes, Reinas y Santas. Modelos de mujer en el mundo hispano, Huelva, Universidad de Huelva, 2007, págs. 247-262.

49 Véase a modo de ejemplo, por los contrastes interregionales en torno a las advocaciones de la luz en Nuestra Señora y en Cristo, SÁnchez Ramos (coord.), Lux Mundi. La religiosidad popular en torno a la luz. En cuanto a los contrastes intrarregionales de una misma advocación, puede verse ARANDA Doncel (coord.), Los dominicos y la advocación del Dulce Nombre de Jesús en Andalucía. Desde la perspectiva de la fiesta ligada a lo religioso, igualmente a modo de ejemplo de comparatismo, Salvador Rodríguez BECERrA, «Fiestas de moros y cristianos en Galicia y Andalucía: análisis comparativo e interpretativo», Boletín auriense, 37 (2007), págs. 357-378. Sobre geografías devocionales, véase la nota n. ${ }^{\circ}$ 48; un caso más, en Ramón MaruRi ViLLanueva, «Presentación» [Enfermedad y religiosidad: un itinerario de la devoción a San Roque en la Cantabria Moderna], en Antonio Montesino González, La rueda de San Roque: comensalismo votivo, sociabilidad e identidad en un ámbito rural de la España atlántica, Santander, Editorial Límite, 1993, págs. 19-43.

50 Véanse Bernarda Palacios González, «Un culto en decadencia: san Indalecio en Almería», en Carlos Álvarez Santaló, M. a Jesús Buxó i Rey y Salvador Rodríguez Becerra (coords.), La religiosidad popular, vol. I, págs. 564-573; Bernard Vincent, «San Benito de Palermo en España», Studia histórica. Historia moderna, 38-1 (2016), págs. 23-38; Enrique Loвo GALindo, «Nuestra Señora de la Encina: emergencia y declinar», en Salvador Rodríguez Becerra (coord.), Religión y cultura, vol. 2, págs. 215-228; Manuel REvuelta González, Enigmas históricos de la Iglesia española contemporánea, Madrid, Universidad Pontificia de Comillas, 2017 (uno de esos enigmas es el del carácter marginal de la devoción al Sagrado Corazón de Jesús tras el Vaticano II).

51 Véanse los siguientes trabajos contenidos en Álvarez Santaló, Buxó i Rey y Rodríguez Becerra (coords.), La religiosidad popular: Pedro Castón BOYER, «Funciones sociales de la religiosidad popular en la sociedad rural y en la sociedad urbana de Andalucía», (vol. I, págs. 453-467); Joxemartin Apalategi BegiRISTAIn, «Religiosidad: cambio y permanencia» (vol. I, págs. 468-477); y Fermín Pardo Pardo, «Pan bendito y caridás en los rituales religioso-populares del campo de Requena-Utiel» (vol. II, págs. 563-584); José Ruiz FERnÁndez, «Entre la tradición y la modernidad: La fiesta de San Marcos en El Ejido (Almería)», en Valeriano Sánchez Ramos y José Ruiz Fernández (coords.), La religiosidad popular y Almería. Actas de las III Jornadas de religiosidad popular, págs. 265-278; Montesıno González, La rueda de San Roque; Clara Macías SÁnchez, Salvador Hernández GonzÁlez y Salvador González Becerra, «Calendario festivo y actos de culto en Carmona: una reflexión acerca de las fiestas en la modernidad», en Revista de Antropología Social, 24 (2015), págs. 405-431. 
historiador modernista, desde la perspectiva de las fuentes, problemas de mayor envergadura que al contemporaneísta y que al antropólogo; esto independientemente de que las transformaciones en el universo devocional, al menos como hechos sistemáticos, mantienen vínculos muy estrechos con el proceso de modernización, y este, sabido es, atañe ya de pleno a la contemporaneidad. 